\title{
THE EFFECT OF FAILURE TO PERFORM CONTRACTS MADE PRIOR TO RECEIVERSHIP
}

The rule that a Receiver is not bound by leases and other executory contracts made prior to his appointment is familiar to every lawyer. In view of the frequency of receiverships, and of the multitude of instances in which receivers have elected not to perform such contracts, one would expect the law as to the consequences of such election to be well settled. There are, however, but few decisions which discuss whether, on principle, a claim for damages, provable as a general claim against the receivership estate, results from failure to perform a contract, no breach of which had occurred prior to the receivership. Two recent decisions of courts of high authority which do contain such a discussion are decidedly at variance. ${ }^{1}$ The importance of the question and the frequency with which it arises justifies a collation of the authorities and a comparison of the reasons urged in the support of the diverse holdings.

Obviously the general question as to liability for breach arises in connection with every conceivable species of executory contract, but the decisions have indicated distinctions more or less questionable between claims founded on leases, claims founded on contracts of employment, and claims founded on other executory contracts such as contracts of sale. The cases may therefore be classified, for purposes of discussion, in three separate groups according to the nature of the contract under consideration.

EXECUTORY CONTRACTS OTHER THAN IEASES OR CONTRACTS

OF EMPLOYMENT

The strongest case in support of the doctrine that claims for breach of contracts of this character are not provable is that of Wells v. Hartford Manilla Company, 76 Conn. 27, 55 Atl. 599. The nature of the case is succinctly stated in the following quotation from the opinion:

"The Fibre Company secured a contract with the Manilla Company for the sale of a quantity of pulp at a

${ }^{2}$ Wells v. Hartford Manilla Co., 76 Conn. 27; Pesnsylvania Steel Company v. N. Y. C. Ry., I98 Fed. 746. 
price several dollars a ton in excess of its market price when the receiver was appointed. The receiver naturally did not regard that as a contract profitable for his estate to adopt. His conduct in not adopting it deprived the vendor of an opportunity to sell 1,200 tons of pulp for something like $\$ 5,000$ more than it was then worth, and pocket the profit. No other element of damage appears in the case."

The Court held:

p. 39:

"In such a case the privilege of the receiver in acting for the best interest of the estate and its creditors not only extends to the right to elect what contracts he will adopt, but also to make the election without at least subjecting the fund required for the satisfaction of existing claims of creditors to a charge for damages. In other words, the consequences of the election under such circumstances may not become the occasion for the allowance of a general claim entitling the claimant to share with other creditors the assets of the estate. Otherwise there might be danger that a portion of an estate which was needed to pay creditors whose claims were already fixed ones might thus be exhausted to their injury."

Discussing the contention that a general claim for damages should be allowed, the Court said, p. $3^{8}$ :

"This conclusion, if sound, would seem to reduce the privilege of election which a receiver admittedly enjoys to microscopic proportions in most cases. Save in those comparatively rare ones where specific performance would for equitable reasons be decreed, the privilege of a receiver would thus be hard to distinguish from that which the ordinary individual or corporation enjoys. Ordinarily a contracting party is privileged to break his contract and pay the resulting damage. The Manilla Company was privileged to do that with respect to this contract. Evidently the rights of receivers in this regard, which the courts have been so solicitous to preserve, are not of so shadowy a character."

It should be noted that there was no uncertainty as to the amount of damages sustained by claimant in this case. ${ }^{2}$

In striking contrast with this decision is that of the Second Circuit Court of Appeals in the case of Pennsylvania Steel Com-

${ }^{2}$ To the same effect, Coy v. Title Guaranty \& Trust Co., 19\& Fed. 275; Brown v. Warnes, 78 Tex. 543 . 
pany v. New York City Railway, ${ }^{2 a}$ allowing a claim of $\$ 44,232.20$ damages for breach of a similar contract. The only possible distinction between the two cases is that in the latter case the corporation in the hands of the receiver had admitted its insolvency and joined in the prayer for the appointment of a receiver (736). The court held that "The admitted insolvency of the city company, followed by the appointment of the receivers, constituted a breach of the contract which was not affected by the fact that the receivers did not notify the claimant of their rejection until some months afterwards."

Whether the receiver in the Connecticut case was appointed by consent does not appear. If not, the decisions of the Connecticut and Federal court may not conflict as to the exact point decided, but there are such vital differences in the principles upon which the decisions are based that it is clear that the courts would frequently reach different conclusions upon an identical state of facts. The Connecticut court considers that creditors whose claims existed prior to the appointment of a receiver have a higher equity than creditors whose only claim is for loss of profits because of breach of a contract subsequent to the receivership.

p. 40 :

"The practical effect of these principles, it is plain to see, is that existing claims have a priority over after-accruing ones of the kind under discussion, arising from the permissible acts of a receiver in his efforts to safeguard the interests of the estate in his hands, and thereby protect the interests of creditors. The other party to a disavowed contract will not thus be deprived of his rights to compensation for any wrong done him, to be obtained in some manner, unless by the obtaining of them he would divert to himself that which by a higher right belongs to others. His rights are simply subordinated to those of others standing in a higher position. The equity of this is apparent. No one suffers unless the insufficiency of assets compels it. If such insufficiency exists, creditors holding claims, the liability for which is fixed when the receiver is appointed, are not obliged in any degree to yield to others who seek to secure to themselves profits which the future, by reason of a good bargain, might have in store for them."

2a 198 Fed. 746-7.

${ }^{3}$ See also I98 Fed. 743; Scott v. Rainier Co., I3 Wash. 108. 
The Federal court on the other hand says: "debts and liabilities, present and future, certain and contingent, stand upon the same equitable basis." I98 Fed. 738.

pp. 739; 740:

"The real inquiry in getting at a basis for the distribution of an insolvent estate is whether the claims are reduced to dollars and cents. If they are so reduced or can be so reduced by the application of recognized principles they are entitled to share. If they are not they cannot share. And this is not at all for any reason affecting their merits nor strictly speaking because they are contingent, but because they are uncertain. So, without laying stress upon the question whether claims are (I) past due, (2) immature, or (3) contingent, the real way we should divide them with respect to the question of provability is into these two classes:

(I) Claims of which the worth or amount can be determined by recognized methods of computation at a time consistent with the expeditious settlement of the estates.

(2). Claims which are so uncertain that their worth cannot be so ascertained.

The first class of claims ought to be proved and share in the estate and this whether they are overdue accounts, immature notes, or claims for damages for breach of contract coinciding with or following the receivership. It is impossible to point to any equitable ground which would justify a court of equity in excluding the holders of any of such claims from sharing in the estate of their debtor." (Italics ours.)

The paragraph last quoted makes it sufficiently clear that the court's decision in allowing the claim was not based primarily upon the theory that consent to the receivership constituted a breach by the corporation antedating the receivership.

Which case is supported by the better reason? Which theory if followed to its logical conclusion will best subserve the ends of justice? The writer offers with diffidence his own comments in the hope that others better qualified may take up the discussion and further elucidate the principles which should govern.

The rule laid down by the Second Circuit Court of Appeals that all claims for damages for breaches prior or subsequent to receivership are provable as a matter of absolute right provided the damages can be computed in dollars and cents has little to recommend it to a court of equity. The maxim that "equality 
is equity," quoted to support this rule, does not tie the hands of the chancellor-witness the rule in railroad receiverships giving a preference to those who furnish labor or supplies within an arbitrary period prior to the receivership. The true meaning of the maxim is that equality is equity between claims supported by equal equities.

But the court says it is "impossible to point to any equitable ground" postponing claims for a subsequent breach of contract to claims of other creditors. Is it true, however, that one who has contributed nothing to the receivership fund, but who merely has a claim for loss of profits which he would have made in the future, has the same equitable right to share equally in the fund with a creditor whose money, labor or material has actually contributed to such fund?

It is said further that "the assets of an insolvent corporation belong to its creditors." But the question is: Who are its creditors within the meaning of the rule?

It is universally held that matured debts, debts certain but not matured, and unliquidated claims for torts or breaches of contract committed prior to a receivership, share equally in the receivership fund. There are good reasons for limiting the right to participate in such fund to claims of this character in all cases where the person or company in the hands of the receiver is insolvent.

The appointment of a receiver is in effect the laying of an equitable execution on all its assets. ${ }^{5}$ This "execution" clearly fixes the priorities of all existing debts over any debts thereafter contracted by the person over whose assets the receiver was appointed. But no debt, liquidated or unliquidated, exists, at the commencement of a receivership, by virtue of an ordinary executory contract of which there has been no breach. To entitle a party to such a contract to classification as a creditor, therefore, it is asserted that mere acquiescence in the appointment of a receiver on account of insolvency amounts to an "out-and-out repudiation, or a complete disablement, and in either case the contract is broken."

To this rule several objections may be urged. First, the actual appointment of a receiver is made by the court, not because of

'See comment of Pitney, J. in Klein v. Gavenesch Co., 64 N. J. Eq. 56; N. Y. P. \& O.R.R. v. N. Y. L. E. \& W. R. R., 58 Fed. $268,282$.

${ }^{5}$ Davis v. Gray, I6 Wall. 217; DuPont v. Standard Arms Co., 81 Atl. (Del.) I089. 
the acquiescence, but because valid grounds for the appointment existed. The appointment may be made notwithstanding opposition and may be refused notwithstanding acquiescence. If performance is rendered impossible, it is the result of an act of the law and the loss is damnum absque injuria. ${ }^{\circ}$ Second, the acquiescence of the corporation is not in fact a repudiation. The obligation to perform survives in the corporation, while an option to perform is conferred on the receiver, coupled with a greater ability to perform than the insolvent corporation itself enjoyed. Third, there is a legal possibility of performance after rejection by the receiver. The receiver may be mistaken in his judgment as to the value of a rejected contract, and the party to the contract may, by a pledge of the proceeds, or otherwise, borrow money to complete it. ${ }^{7}$ The lien of the receiver attaches only to assets owned at the commencement of the receivership by the insolvent company or individual whose property is the subject of the receivership. ${ }^{8}$ Fourth, insolvency, coupled with the appointment of a receiver does not amount to a breach eo instanti entitling the other party to an executory contract, to damages. The other party must himself tender performance, and prove his ability to perform, before his right to damages, as distinguished from his right to rescission, accrues. This statement is directly supported by the decision of the United States Supreme Court in Florence Mining Co. v. Brozen, I24 U. S. 385 , at page $389 . .^{9}$ The decisions of the same court, cited as authority for the doctrine that receivership or bankruptcy constitutes an anticipatory breach, ${ }^{10}$ merely hold that there may be an anticipatory breach, giving rise to a claim for damages before performance is due, not that receivership or bankruptcy is in fact such a breach. ${ }^{\text {II }}$ If

- Griffith v. Boom \& Lumber Co., 46 W. Va. 56. See also DuPont v. Standard Arms Co., 8I Atl. (De1.) I089; Malcomson v. Wappoo Mills, 88 Fed. 680. See also Atl. Trust Co. v. Chapman, 208 U. S. 370.

'Sparhaze v. Yerkes, I42 U. S. I. That a corporation may do acts which do not interfere with the Receiver, $O$. \& $M$. Ry. v. Russell, II5 III. 52, 57. Even when a receiver has been appointed in dissolution proceedings, the possibility of a resumption of business by the corporation has been recognized. People v. Metropolitan Surety Co., 205 N. Y. I42.

${ }^{8} 34$ Cyc. 19o; Gabert v. Olcott, 22 S. W. (Tex.) 286.

'Diem v. Koblitz, 49 O. S. 4I, 56.

${ }^{10}$ Roehnn v. Horst, I78 U. S. I; Lovell v. St. Louis Life Ins. Co., III U. S. 264 .

II If a voluntary receivership on account of insolvency operates as a breach of executory contracts, voluntary bankruptcy would also constitute 
the receivership terminated a few days after the appointment of a receiver by acquiescence, is it not certain that no action at law for damages would lie until "performance or an offer to perform ..... with an ability to make good the offer if accepted"?" In receivership cases, "rights should be determined on legal principles where such exist." ${ }^{13}$ Fifth, acquiescence because of actual insolvency is not voluntary. ${ }^{14}$

There are several decisions in other jurisdictions upon the question of the provability of claims of the general character discussed in this subdivision. The Supreme Court of West Virginia, in an important and bitterly contested case, held that one who had a contract to cut timber, which had been partly performed when a receiver was appointed for the party for whom the timber was to be cut, was entitled to just and reasonable compensation for labor and money necessarily expended in part performance, but not to profits. ${ }^{15}$

such a breach. The decisions as to the effect of bankruptcy are not harmonious, but the majority hold that bankruptcy constitutes an anticipatory breach. Scott v. Transfer Co., $32 \mathrm{~A} . \mathrm{B}, \mathrm{R}$. 417; In re Pettingill, I37 Fed. I43; In re Neff, I57 Fed. 57; Cf. Watson v. Merrell, I36 Fed. 359. There is language in several of the cases which justifies the inference that it is optional with the creditor to treat the bankruptcy as a breach and prove his claim with the Trustee, or pursue whatever remedy he has against the bankrupt personally, treating the contract as one not discharged by bankruptcy. It was so held in Phoenix National Bank $v$. Waterbury, 23 A. B. R. 250; I97 N. Y. 161. The bankrupt, after discharge, was held personally liable for breach of an executory contract, which, under the Federal decisions above cited, must have been provable as a claim in bankruptcy. (Cf. Wood v. Fisk, 3I A. B. R. 827, 829.) If the New York decision is correct, the provability of such claim and, consequently, the question whether the bankrupt is discharged from liability upon it, depends upon the election of the creditor to prove or not to prove it. It is doubtful whether the U. S. Supreme Court would so hold. Friend v. Talcott, 228 U. S. 27, 37, 38; Crawford v. Burke, 195 U. S. I76, 193.

${ }^{12}$ Florence Mining Co. v. Brozen, I24 U. S. $385,389$.

${ }^{23}$ DuPont v. Standard Arms Co., 8I Atl. (Del.) Io89.

${ }^{13}$ Griffith v. Boom \& Lumber Co., 46 W. Va. 56: "The appellee, Thompson, claims that the dissolution of the corporation was voluntary for the reason that the officers assented thereto. They assented because its business had assumed such a condition that it could not be continued without great loss to its creditors and stockholders, hence such dissolution was not voluntary but was brought by force of circumstances, and the final determination of its affairs shows that it was not solvent."

${ }^{15}$ Griffith $v$. Boom \& Litmber Co., 46 W. Va. 56. This claim, because of special circumstances, was allowed as a preferred claim, in effect a 
In Malcomson v. Wappoo Mills, 88 Fed. 680 (Cir. Ct. S. C.) the facts were quite similar to those in Wells v. Hartford Manilla Co. A claim for damages was disallowed on the ground that the appointment of the receiver rendered performance impossible and such impossibility was an impossibility occasioned by law.

It is sometimes said that a receivership "furnishes an efficient mode of being relieved of unprofitable and embarrassing executory contracts..$^{18}$ For whose benefit? Not for the benefit of the corporation itself, for all its assets are abandoned to the receiver; the company itself remains liable on the contract; and a claim for damages, if the contract is not performed by either the receiver or the company, may properly be allowed as a claim payable out of any assets not needed for the payment of other debts. The Connecticut court recognizes, as every court should, the propriety of a conditional allowance of claims for breaches occurring subsequent to the receivership, i. e. an allowance conditioned on the existence of assets in excess of fixed liabilities which would otherwise go to the company or its stockholders. ${ }^{17}$

It is generally held that claims on surety bonds or insurance policies are not provable against the assets of an insolvent company unless the condition fixing the amount of liability had occurred prior to the receivership. It was so held in a recent decision by the New York Court of Appeals, in which the question as to when the corporate assets constituting the trust fund were to be marshalled, equities adjusted, and claims allowed, was carefully reconsidered. ${ }^{18}$ While the case involved the construction of a statute it was decided largely on general principles, and the court declared that the rule adopted by it was "applied by. courts of equity and bankruptcy and to the distribution of assets under general assignments, for the benefit of creditors." The Circuit Court of Appeals, for the 2d Circuit, however, held, as

receiver's liability, but in a later decision in the same case the court practically concedes that it was in error in allowing such preference, 55 W. Va. 604, 607, 630 .

${ }^{16}$ Alderson on Receivers, Sec. 270; High, Sec. 328.

${ }^{17}$ Wells v. Hartford Manilla Co., 76 Conn. 27; People v. Metropolitan Surety Co., 205 N. Y. I46. If such claims are not allowed, the holder should be allowed to intervene and compel the termination of a receivership as soon as its creditors can be paid, thus releasing the assets to the original owner in whose hands they would at once be subject to levy. Heath v. M. T. K. Ry., 83 Mo. 6r7.

${ }^{18}$ People v. Metropolitan Surety Co., 205 N. Y. I39. 
we have seen, that the provability of claims is to be determined, not by their condition at the time of the appointment of the receiver, but by their condition at any time prior to the expiration of the time allotted by the court for the presentation of claims. ${ }^{19}$

The English decisions allow proof of claims for damages for failure to perform executory contracts as unpreferred claims against the property in the hands of the managing receiver, apparently without reference to whether the contract is one for service, ${ }^{20}$ sale, $^{21}$ or lease. ${ }^{22}$ New Jersey alone of the United States seems to be equally liberal in its allowance of such claims. ${ }^{23}$

\section{CLAIMS FOR DAMAGES FOR BREACH OF LEASE}

The reasons urged above against the allowance of claims for damages for subsequent breaches of ordinary contracts are equally forcible against the allowance of claims by a lessor for damages for breach of a contract to pay rent. The following quotation shows the reasons given by the C. C. A. for Second Circuit, for denying the provability of such a claim in bankruptcy. ${ }^{24}$

In re Roth \& Appel, r8I Fed. 667:

"Rent is a sum stipulated to be paid for the use and enjoyment of land. The occupation of the land is the con-

${ }^{10}$ I98 Fed. 741.

${ }^{20}$ Parsons v. Bank of Canada, 1912, 29 T. L. R. 38; Reid v. Explosives Co., L. R. I9 Q. B. D. $264 ; 24$ Laws of England, 429.

${ }^{21}$ Newdigate, Colliery in re Newdigate, I912, I Ch. 468, 474, 477.

${ }^{22}$ Ex Parte Llynnvi Coal Co. in re High, 7 L. R. Ch. App. 228. This case construed a bankruptcy statute.

${ }^{23}$ Bolles v. Crescent Drug Co., 53 N. J. Eq. 614 (Contract or lease); Spader v. Mural Co., 47 N. J. Eq. I8 (Service); Klein v. Gavenesch Co., 64 N. J. Eq. 5r. (Claim for rent accruing to end of lease disallowed, but without prejudice to presentation of claim for damages based on equitable principles.)

${ }^{24}$ See also In re Scott Transfer Co., 32 A. B. R. 4I7. Contra, In re Kaloris Mfg. Co., 24 A. B. R. 609.

Some, at least, of the reasons given for differentiating claims for rent from claims for breach of an executory contract to purchase are specious. Thus the goods to be delivered are as much the consideration of the price to be paid, as the occupation is the consideration for rent. No debt is created until delivery. Also the vendee may excuse performance or render performance impossible, just as a lessor may consent to an assignment of the lease or the abandonment of the premises. Performance of either contract may be prevented by act of the contractor, or vis major. 
sideration for the rent. If the right to occupy terminate, the obligation to pay ceases. Consequently, a covenant to pay rent creates no debt until the time stipulated for the payment arrives. The lessee may be evicted by title paramount or by acts of the lessor. The destruction or disrepair of the premises may, according to certain statutory provisions, justify the lessee in abandoning them. The lessee may quit the premises with the lessor's consent. The lessee may assign his term with the approval of the lessor, so as to relieve himself from further obligation upon the lease. In all these cases the lessee is discharged from his covenant to pay rent. The time for payment never arrives. The rent never becomes due. It is not a case of debitum in praesenti solvendum in futuro. On the contrary, the obligation upon the rent covenant is altogether contingent."

The contingent character of such claims is also emphasized in the decision of People v. Metropolitan Insurance Company, 205 N. Y. 139 , in which a claim upon a surety bond was disallowed although the exact amount due was fixed shortly after the receivership. ${ }^{25}$

The Supreme Court of Massachusetts has held that a lessor is entitled to prove his claim against the estate of an insolvent debtor for rent accruing up to the time of settlement, but is "not entitled to prove any claim for or on account of rent payable in the future. As regards future rent there has been no breach of the covenant in the lease that will sustain an action either for rent or for damages."26

A United States Circuit Judge in Ohio disallowed a claim against the receiver of an insolvent national bank for damages to the lessor resulting from the failure of the bank and its receiver to perform the obligations of the lease. ${ }^{27}$

In another branch of the decision in Pennsylvania Steel Company v. New York City Railway, reported in 198 Fed. pages $75^{8-9}$, the court refused to allow a claim for damages for breach

${ }^{25}$ This decision does not refer to the former decision of the same court in People v. St. Nicholas Bank, I5I N. Y. 592, in which a claim for deficiency in rentals was allowed where the lessor had leased the premises at a diminished rental after they had been abandoned by the receiver. Both decisions dealt with receiverships in proceedings for the dissolution of corporations.

${ }^{26}$ Deane v. Caldwell, I27 Mass. 242.

${ }^{27}$ Fidelity Trust \& Savings Co. v. Armstrong, 35 Fed. 567. See also N. Y. P. \& O.R. R. v. N. Y. L. E., 58 Fed. 268. 
of a long term lease of a railroad system which the receivers had not rejected prior to the expiration of the time fixed for proof of claims but which they did reject later. The claim was apparently disallowed because of the impossibility of proving the amount of damages at the time the claim was required to be proved. ${ }^{28}$

Cases in other jurisdictions, however, have generally allowed the lessor some measure of relief. A Minnesota court ${ }^{2 \theta}$ allowed estimated damages to a lessor for the balance of the term, but in that case the lessee was a corporation which had itself petitioned for dissolution and the court held that the dissolution of the corporation operated as a final breach of the lease forever preventing the lessee from carrying out the obligations of the lease. The proceedings being governed by statute, the court held that the same rule must apply whether the corporation applying for dissolution was solvent or insolvent. In the event of a solvent corporation such claim should of course be allowed.

In an Illinois case, ${ }^{30}$ it was held that the landlord was "entitled, as a claim upon the assets to be paid pro rata with other creditors, to the rent for which at the time of such allowance the insolvent might be liable, according to the terms of the lease."

In the case of Hartford Deposit Co. v. Chemical Bank, ${ }^{31}$ the Illinois courts allowed a claim of $\$ 9000.00$ for rent accruing

${ }^{28}$ I98 Fed. 759: "The difficulty, however, with any demand for future damages is that in January, 1908, when the time limited for the presentation of claims against the Metropolitan estate expired, it was wholly impossible to determine the amount of damages which the claimant would sustain if the receivers renounced the lease and it was treated as broken. It was impossible then to say whether any provisional arrangement could be made for future operation by the receivers, and if it had been possible to forsee the terms of the provisional arrangement only one step would have been taken. It would have been impossible to look into the future and say what would be the result upon the conclusion of such arrangement and the surrender of the road. Who could fortell the results of operation by the owner, the growth of the city, improvements in motive power, or reductions in cost? Who could forsee whether a lease could be made to another railroad company or the terms thereof? The whole matter of future damages was and still is a matter of conjecture and guess work. The claim for such damages was properly disallowed because it was uncertain in amount and there was no method of making it certain."

${ }^{20}$ Kalkhoff v. Nelson, 60 Minn. 284.

${ }^{20}$ Chicago Fire Place Co. v. Tait, 58 Ill. App. 293.

${ }^{1}$ Reported at various stages, 58 Ill. App. 256, I56 Ill. 522, I6I U. S. I. The syllabus of this case, as reported in I6r U. S. I, is somewhat mis- 
between the date when the receiver abandoned the premises and the date when the premises were re-let at a reduced rental. Damages for the remainder of the term, after the re-letting, though liquidated by the new lease, were apparently not claimed, and were certainly not allowed.

Cases in Maryland, Michigan and $\mathrm{Ohio}^{32}$ allow the lessor to prove his claim as a general creditor for rent which had accrued after the receivership prior to distribution. In a Pennsylvania case $^{33}$ the lessor was allowed as damages for breach of the lease the "loss he suffers by reason of the difference of the rentals now obtainable in consequence of the peculiar arrangement and construction of the premises, and the rental agreed upon as an inducement to him to make the investment for the use of the company." Undoubtedly special damages resulting to a lessor by reason of expense in specially fitting 'up premises for a lessee, by improvements which could not be availed of by tenants generally, would be allowed under the Connecticut rule. ${ }^{34}$

In a recent decision ${ }^{35}$ it was held that the receiver of a lessor was not bound by a covenant to renew a lease of a portion of premises of which the receiver had taken possession. Special damages incurred by the lessee in fitting up the premises on the faith of the renewal clause were allowed but the liquidated damages stipulated in the lease were not allowed. If this

leading. The case is often cited as if the Supreme Court of the United States had approved the holding of the Illinois Court. Careful reading of the decision shows, however, that the only federal question considered was whether the receivership terminated the existence of the company. A quotation in the opinion from the Illinois decisions as to the damages allowed is followed by the statement at p. 10: "Clearly the conclusion thus reached involved no denial of a title, right, privilege, or immunity specially set up or claimed under the laws of the United States, and, as already seen, the only Federal question arising was rightly decided."

"Gaither v. Stockbridge, $67 \mathrm{Md}$. 222; Woodland v. Wise, II2 Md. 35; Marshall v. Caverly Co., I8 O. D. 157; McGraw v. Union Trust Co., I35 Mich. 609; Johnston v. Amos, II4 Iowa, 532, obiter.

See also Marten v. Black, 9 Paige, 64I; Tradesmen Publishing Co. v. Knoxville Car Wheel Co., 95 Tenn. 634.

Similar allowance was made of a claim against an assignee for the benefit of creditors in Smith $v$. Goodman, I49 I1l. 75; 50 Wilder $v$. McDonald, 63 O. S. 383 , obiter.

${ }^{33}$ Reading Iron Works, $150 \mathrm{~Pa}$. St. 369.

${ }^{3}$ Wells v. Hartford Manilla Co., 76 Conn. 27; Coy v. Title Guaranty Trust Co., I98 Fed. 275, 283.

${ }^{s 5}$ Coy v. Title Guaranty Trust Co., 198 Fed. 275-283. 
decision is authority for the proposition that the receiver of a lessor may take possession of the leased premises and terminate a lease, or refuse to comply with a covenant for renewal, without subjecting the estate to damages, it constitutes an unjustifable and unprecedented extension of the receiver's privilege. If a lease of property is so burdensome that as a result the property produces no revenue or causes a loss, the receiver might abandon the property and with it the lease, ${ }^{36}$ but if he elects to take the property he must take it subject to the lease. ${ }^{37}$ As privity of estate, rendering the receiver of a lessee liable for rent, is created between the receiver and the lessor where the receiver of the lessee adopts a lease, ${ }^{38}$ so privity of state, binding the receiver of a lessor to comply with the lease, is created when the receiver of the lessor elects to take the land of the lessor as an asset.

Before leaving this subject it is interesting to note that grasping lessors, who seek to prove a claim against an insolvent estate for rent accruing for the entire balance of the term, may find disagreeable consequènces attached to such procedure. In $W i l-$ son v. Pennsylvania Trust Co., II4 Fed. 742, the Circuit Court of Appeals of the Third Circuit said that assuming the validity of a provision in a lease that the whole rent for the balance of the term would become due and payable if the lessee should become bankrupt these consequences would follow: Rent for the entire residue of the term would be provable as an unpreferred debt and the unexpired portion of the term would become an asset of the bankrupt's estate to be disposed of by the trustee in bankruptcy for the benefit of the estate.

\section{CLAIMS FOR DAMIAGES FOR BREACH OF CONTRACTS OF EMPLOYMENT}

The development of the law as to the effect of the appointment of a receiver upon executory contracts of employment is especially interesting.

Early English decisions, ${ }^{39}$ established a rule that there is an implied condition in contracts of service that the death of the

${ }^{30}$ Equitable Loan \& Security Co. v. R. L. Moss \& Co., I25 Fed. 609; In re Jersey Island Packing Co., I38 Fed. 625.

${ }^{37}$ Sparhawk v. Yerkes, I42 U. S. I, I3; Sunflower Oil Co. v. Wilson, 142 U. S. 322.

"U. S. Trust Co. v. Wabash Railway, I50 U. S. 300.

"Farrow v. Wilson, L. R. 4 C. P. 744. 
master or servant shall terminate the contract. The English courts have not, however, held that the appointment of a receiver was so analogous to death, that contracts of employment terminated pursuant to an implied condition, upon the appointment of a receiver for either party. If a contract of employment is terminated by receivership, the English courts allow damages, as in the case of other executory contracts. ${ }^{40}$

But American courts have almost universally held that the appointment of a receiver for the master's property is an act of the law preventing performance by either party, terminating the contract pursuant to an implied condition, and therefore not giving rise to a claim for damages for its breach. They distinguish contracts for service from other contracts by reference to the old rule as to termination of such contracts by death.11

While the result arrived at by the American decisions, i. e., that damages should not be allowed, is correct, it does not seem that the reasons for differentiating contracts of service from other contracts are satisfactory.

First, the original rule as to contracts of service was based on the presumption that both parties relied on the personality of the other party to the contract. When the personality of either ceased to exist the contract terminated. It did not terminate merely because one of the parties became unable to fulfill it because of insolvency. The employer, corporate or individual, still exists as a separate legal entity or personality, notwithstanding a receivership. This legal entity remains personally liable for the breach of the contract. ${ }^{.2}$

Second, the rule was equally applicable to master and servant. Would anyone contend, however, that the appointment of a

${ }^{\circ 0}$ Reid v. Explosives Co., L. R. 19 Q. B. D. 264; 24 Laws of Eng. 429.

"DuPont v. Standard Arms Co., 8I Atl. (Del.) I089 (gen'l manager, Receivership); Lenoir v. Linville Improvement Co., 126 N. C. 922, $5 \mathrm{I}$ I. R. A. I46 (officer-Receivership); Eddy v. Co-operative Dress Ass'n, 3 N. Y. Civ. Pro. 442 (Receivership-gen'l manager); Williamson County Banking \& Trust Co. v. Roberts Buford Co., 9 I. R. A. (N. S.) 644 (Receivership on account of insolvency-officer); Laws v. Waldron, 230 Pa. St. 458 (Receivership-gen'l agent); Referee v. Globe Ins. Co., 9I N. Y. I74 (Involuntary dissolution-officer); Contra: Spader v. Mural Co., 47 N. J. Eq. I8; Rosenbaum v. Credit System Co., 6I N. J. L. 544, 548 .

The N. J. cases, however, were laying down a rule of construction of a statute applicable to dissolution of solvent, as well as insolvent, corporations.

$\therefore$ Potts v. Rose Valley Metals Co., I67 Pa. 3 ro. 
receiver of the assets of an individual, who was under contract to perform certain personal services, could be treated by his employer as a breach of contract?

Third, the reason for the old rule as to contracts between master and servant does not apply where the employer is a corporation. The personality of every individual interested in a corporate employer may change by a transfer of the stock, but the entity, which is in law the employer, remains unchanged, and the employe remains bound by his contract.

Fourth, the fact that the appointment of a receiver of the assets of a corporation is an act of the law, which prevents further payment of the employe out of the assets of the corporation as effectually as death prevents further payment of wages out of the assets of the decedent, is undoubtedly the underlying reason why courts have seized upon this analogy. But if the receivership is treated as an act of the law, which, therefore terminates contracts of employment without liability for breach, it must logically be given the same effect in respect to other executory contracts.

\section{CONCLUSION}

From the above review of the decisions, it appears that the distinctions attempted to be drawn between the effect of receivership upon leases, employment contracts and other contracts, do not rest on a satisfactory basis.

There is a satisfactory and logical basis for a distinction between claims for breach by an act of the party, accruing prior to the time when assets are sequestered by the appointment of a receiver, and claims for damages for breaches subsequent to that date.

In accordance with settled principles, equity follows the law in estimating the damages for breaches by act of the party, occurring prior to the receivership, and such measure of damages frequently includes such items as future profits. But a court of equity is not constrained to hold that its own act in appointing a receiver for the benefit of existing creditors is equivalent to an immediate breach of contract by the party over whose assets the receiver is appointed. Nor is it constrained to hold that persons whose claims arise subsequent to its "equitable execution" have an absolute right to share in the property sequestered thereby. If any party has sustained actual damages in preparation for per- 
formance of an executory contract, giving rise to a claim which, "upon the principles of equity and conscience, which underly receivership proceedings," ought to be allowed, the chancellor may allow such claim, but the measure of damages would not be governed by legal rules as to damage for breach of contract, and would probably never include future profits. ${ }^{43}$

Of such a rule it may undoubtedly be said that, in effect, it leaves to the discretion of the chancellor, in each particular case, the decision whether or not a claim for damages, arising out of failure to perform an executory contract, should be allowed. The answer is that justice is better subserved by giving the chancellor such discretion than by the arbitrary rule that a receivership operates as a breach, giving persons, who have contributed nothing to the receivership fund, rights in it equal with those whose contributions have created it. If the person having such a claim does not wish to trust to the discretion of the chancellor, he may retain his personal claim for full damages against the company or individual whose property is in the hands of the receiver.

Charles P. Hine.

Cleveland, OHio.

"Wells v. Hartford Manilla Co., 76 Conn. 27; Coy v. Title, Guaranty \& Trust Co., 198 Fed. 275, 283-4. 